\title{
Stand mixing effect on enzyme activity and other soil properties
}

\begin{abstract}
In this research study, enzyme activity was used to assess differences occurring in soils as a result of the different tree species influence. The aim of the study was to assess the effects of Scots pine (Pinus sylvestris), sessile oak (Quercus petraea) and mixed-species stands on the enzymatic activity and chemical characteristics of soil. Sample plots were located in central Poland, in the Przedbórz forest district $\left(51.09 .59 .50^{\circ} \mathrm{N}, 20.00 .24 .25^{\circ} \mathrm{E}\right)$. The test area was dominated by Brunic Arenosols. 15 research plots were established ( 5 plots under pine, 5 plots under oak and 5 plots under mixed-species stand). Soil samples from the $\mathrm{O}, \mathrm{A}$ and $\mathrm{AB}$ horizons were taken. In soil samples $\mathrm{pH}$, soil texture, and organic carbon, nitrogen, base cation contents, dehydrogenase activity and urease activity were determined. Tree species affected soil organic matter accumulation, $\mathrm{pH}$ and microbial activity. The highest enzyme activity was reported in the soils under oak and mixed-species stands. The soil $\mathrm{pH}$ was lower under pine forest than under oak and mixed-species stands. pHs is presumably a major factor affecting microbial community composition and enzyme dynamics. We noted a significant correlation between enzyme activity and $\mathrm{C} / \mathrm{N}$ ratio which is often used to describe litter quality. A lower $\mathrm{C} / \mathrm{N}$ ratio was found in oak and mixed-species stands compared with pine stands.
\end{abstract}

Keywords: Soil organic matter, Dehydrogenase and urease activity, Forest soils, Sessile oak, Pine

\section{INTRODUCTION}

In the recent years a lot of attention has been devoted to the mixed-species stands (Pretzsch et al. 2015 and 2016). Mixed-species stands are characterized by both higher productivity and greater resistance and stability (Río and Sterba 2009, Río et al. 2014). Pretzsch et al. (2016) observed positive additive and multiplicative mixing effects on structural heterogeneity as well as stand productivity. Mixed stands compared to monocultures stands have a greater above-ground nutrient content, indicating an increase in the proportion of resources accumulated from a site (Richards et al. 2010) and sequestration of carbon (Jandl et al. 2007, Wolińska et al. 2015). In Poland the mesotrophic sites are dominated by pine monocultures in the lowlands and by spruce monocultures in the mountains. Mesotrophic sites create ideal conditions for the simultaneous growth of coniferous and deciduous species such as beech and oak (Lasota and Błońska 2013). Mixed-species stands used sites possibilities optimally and ensure high productivity. The ecological space is better use by deciduous and coniferous species with different requirements (Pretzsch 2014). Species composition of trees affects mainly the properties of surface soil horizons (Błońska et al. 2016). Stand effect is mainly reflected in the type and quality of humus. Numerous studies describe the influence of the species composition of the stand on the physico-chemical properties of soils (Paluch and Gruba 2012, Gałka et al. 2014, Labaz et al. 2014) fewer papers describe the changes in the biochemical properties (Błońska et al. 2016).

The aim of this study is to assess the impact of poor pine stands, oak stands and mixed-species stands (pine and oak) on soil properties. The physic-chemical properties and biochemical properties expressed as enzymatic activity were used in the monitoring of these differences. The following hypotheses were tested: 1) soil of mixed-species stands (pine and oak) have favorable properties of humus and higher biochemical activity compared to pine stands growing on similar soils 2) increasing share of deciduous species improves the quality of soil organic matter 3) the most beneficial effect on the activity of dehydrogenase and urease were oak stands.

\section{MATERIALS AND METHODS}

\section{Study sites}

The study sites are located in central Poland (Przedbórz Forest District) under different tree stands pine (P. sylvestris), sessile oak (Quercus petraea) and mixed-species stand (pine (P. sylvestris) plus sessile oak (Quercus petraea)). The local soils are derived from sandy fluvio-glacial deposits. The soils were classified as Brunic Arenosols (WRB 2006). On each 
of the 15 research plots ( 25 ar) soil samples from $O$, $\mathrm{A}$ or $\mathrm{AB}$ horizons were taken. Two samples were collected from each plot. Five subsamples were collected from each horizon and were thoroughly mixed to give a composite soil sample. We sampled the $\mathrm{O}, \mathrm{A}$ and $\mathrm{AB}$ horizon according to the observed depths. The samples for laboratory analysis were collected in September in 2008. For the determination of enzymatic activity, one part of fresh samples with natural moisture were passed through a sieve $(\varnothing 2 \mathrm{~mm})$ and stored at $4^{\circ} \mathrm{C}$ before the analysis. For an analysis of physical and chemical properties, samples were airdried at room temperature condition and then sieved.

\section{Laboratory analysis}

In the samples soil texture was determined using the laser diffraction (Analysette 22, Fritsch, Idar-Oberstein, Germany), soil $\mathrm{pH}$ was analysed in distilled water and $\mathrm{KCl}$ using the potentiometric method. The content of total nitrogen $\left(\mathrm{N}_{\mathrm{t}}\right)$ and organic carbon $\left(\mathrm{C}_{\mathrm{t}}\right)$ content were measured using LECO CNS True Mac Analyzer (Leco, St. Joseph, MI, USA), including the calculation of the $\mathrm{C} / \mathrm{N}$ ratio. Base cations $\left(\mathrm{BC}=\mathrm{Ca}^{2+}\right.$, $\mathrm{Mg}^{2+}, \mathrm{K}^{+}, \mathrm{Na}^{+}$) were determined by inductively coupled plasma-optical emission spectrometry (ICP-OES) (iCAP 6500 DUO, Thermo Fisher Scientific, Cambridge, UK).

Dehydrogenase activity (DH) was determined by the reduction of 2,3,5-triphenyltetrazolium chloride (TTC) to triphenyl formazan (TPF) using Lenhard's method according to the Casida procedure (Alef and Nannipieri 1995). Briefly, $6 \mathrm{~g}$ of soil was incubated with $1 \mathrm{ml}$ of $3 \%$ TTC for $24 \mathrm{~h}$ at $37^{\circ} \mathrm{C}$. TPF was extracted with ethyl alcohol and measured spectrophotometrically. Urease activity (UR) was determined according to Tabatabai and Bremner (1972) using a water-urea solution as a substrate. This activity was determined by the $\mathrm{NH}_{4}^{+}$released after a $2 \mathrm{~h}$ incubation at $37^{\circ} \mathrm{C}$. The concentration of $\mathrm{NH}_{4}^{+}$was measured at $410 \mathrm{~nm}$ by the colorimetric method (Alef and Nannipieri 1995). In the soil samples the activity of dehydrogenase (EC 1.1.1.1) and urease (EC 3.5.1.5) were determined in three repetitions.

\section{Statistical analysis}

Differences between the mean values were evaluated with the nonparametric Kruskal-Wallis test. In order to reduce the number of variables in the statistical data set and to visualize the multivariate data set as a set of coordinates in a high-dimensional data space, the Principal Component Analysis (PCA) method was used. The PCA method was also used in order to interpret other factors, depending on the type of data set. All statistical analyses were performed with Statistica 10 software (2010).

\section{RESULTS}

The $\mathrm{pH}_{(\mathrm{H} 2 \mathrm{O})}$ ranged from 2.98 to 3.97. Soils of oak stands displayed the highest $\mathrm{pH}$ values (3.87) noted in the A horizon of oak soil (Table 1). The carbon content in organic horizons of pine and mixed-species stand ranged from 17.52 to $19.60 \%$. The best degree of decomposition of soil organic matter expressed as the $\mathrm{C} / \mathrm{N}$ ratio was attributed to oak stands (mean $\mathrm{C} / \mathrm{N}$ ratio 11-13) in $\mathrm{A}$ and $\mathrm{AB}$ horizon, respectively. The

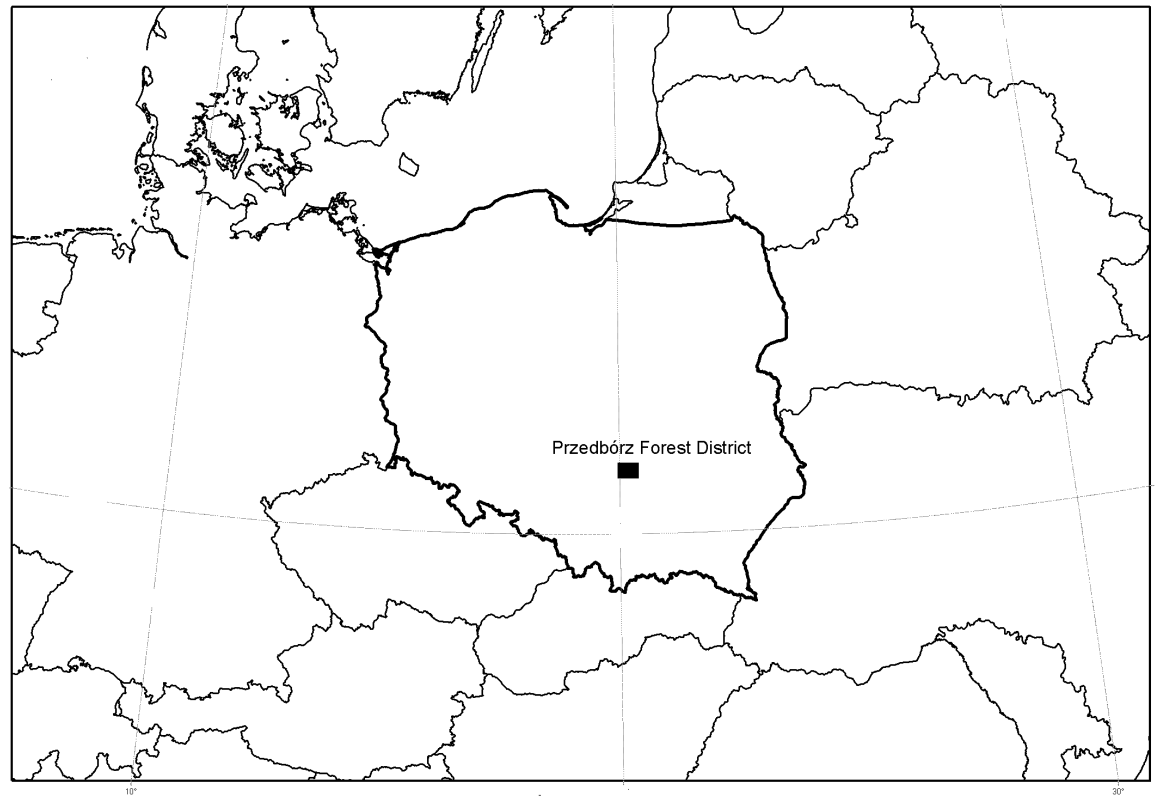

FIGURE 1. Localization of research area (Poland, Przedbórz Forest District) 
TABLE 1. Properties of soil under different forest stand (mean and standard deviation)

\begin{tabular}{llrllllll}
\hline$=$ Plots & Horizon & $\mathrm{C}$ & $\mathrm{N}$ & $\mathrm{C} / \mathrm{N}$ & $\mathrm{DH}$ & $\mathrm{AU}$ & $\mathrm{pH}$ & $\mathrm{pH}$ \\
& & & & & & $\mathrm{H}_{2} \mathrm{O}$ & $\mathrm{KCl}$ \\
\hline $\mathrm{P}$ & $\mathrm{O}$ & $19.60 \pm 6.10^{\mathrm{a}}$ & $0.75 \pm 0.34^{\mathrm{a}}$ & $27.26 \pm 4.63^{\mathrm{a}}$ & $9.70 \pm 4.19^{\mathrm{a}}$ & $9.10 \pm 2.99^{\mathrm{a}}$ & $3.80 \pm 0.23^{\mathrm{a}}$ & $2.98 \pm 0.19^{\mathrm{a}}$ \\
& $\mathrm{A}$ & $2.41 \pm 0.56^{\mathrm{a}}$ & $0.10 \pm 0.03^{\mathrm{a}}$ & $23.27 \pm 1.24^{\mathrm{a}}$ & $3.46 \pm 2.21^{\mathrm{b}}$ & $3.74 \pm 1.51^{\mathrm{b}}$ & $4.10 \pm 0.37^{\mathrm{a}}$ & $3.41 \pm 0.27^{\mathrm{a}}$ \\
\hline $\mathrm{P}-\mathrm{O}$ & $\mathrm{O}$ & $17.52 \pm 4.64^{\mathrm{a}}$ & $0.75 \pm 0.18^{\mathrm{a}}$ & $23.25 \pm 2.51^{\mathrm{a}}$ & $25.44 \pm 7.59^{\mathrm{a}}$ & $12.88 \pm 3.46^{\mathrm{a}}$ & $4.03 \pm 0.21^{\mathrm{a}}$ & $3.26 \pm 0.30^{\mathrm{a}}$ \\
& $\mathrm{A}$ & $2.14 \pm 0.64^{\mathrm{a}}$ & $0.10 \pm 0.04^{\mathrm{a}}$ & $20.98 \pm 1.86^{\mathrm{a}}$ & $3.10 \pm 4.83^{\mathrm{b}}$ & $3.59 \pm 1.97^{\mathrm{b}}$ & $4.34 \pm 0.37^{\mathrm{a}}$ & $3.64 \pm 0.36^{\mathrm{a}}$ \\
\hline $\mathrm{O}$ & $\mathrm{A}$ & $1.52 \pm 0.74^{\mathrm{a}}$ & $0.13 \pm 0.02^{\mathrm{a}}$ & $11.00 \pm 3.66^{\mathrm{b}}$ & $38.24 \pm 14.27^{\mathrm{a}}$ & $13.19 \pm 3.77^{\mathrm{a}}$ & $4.65 \pm 0.28^{\mathrm{a}}$ & $3.87 \pm 0.39^{\mathrm{a}}$ \\
& $\mathrm{AB}$ & $0.72 \pm 0.49$ & $0.05 \pm 0.02$ & $12.85 \pm 3.46$ & $1.43 \pm 1.14$ & $2.55 \pm 0.87$ & $4.71 \pm 0.40$ & $3.97 \pm 0.32$ \\
\hline
\end{tabular}

Different small letters in the upper index of the mean values mean significant differences. DH - dehydrogenases activity $\left(\mu \mathrm{M}\right.$ TPF $\cdot \mathrm{kg}^{-1} \mathrm{soil}^{-1} \mathrm{~h}^{-1}$ ); $\mathrm{AU}$ - urease activity $\left(\mathrm{mM} \mathrm{N}-\mathrm{NH}_{4} \cdot \mathrm{kg}^{-1} \mathrm{soil}^{-1} \mathrm{~h}^{-1}\right) ; \mathrm{C}, \mathrm{N}[\%] ; \mathrm{P}-$ pine forest, $\mathrm{O}-$ oak forest, $\mathrm{P}-\mathrm{O}-$ mixed-species stand (pine + oak).

TABLE 2. Base cations content and texture of soil under different forest stand (mean and standard deviation)

\begin{tabular}{lllllllll}
\hline Plots & Horizon & $\mathrm{Ca}^{2+}$ & $\mathrm{Mg}^{2+}$ & $\mathrm{K}^{+}$ & $\mathrm{Na}^{+}$ & sand & silt & clay \\
\hline $\mathrm{P}$ & $\mathrm{O}$ & $79.68 \pm 31.76^{\mathrm{a}}$ & $7.69 \pm 0.34^{\mathrm{a}}$ & $15.71 \pm 6.01^{\mathrm{a}}$ & $1.98 \pm 0.32^{\mathrm{a}}$ & - & - & - \\
& $\mathrm{A}$ & $9.88 \pm 5.38^{\mathrm{a}}$ & $0.75 \pm 0.34^{\mathrm{b}}$ & $1.94 \pm 0.55^{\mathrm{b}}$ & $0.73 \pm 0.24^{\mathrm{a}}$ & $91.40 \pm$ & $6.00 \pm 1.22^{\mathrm{b}}$ & $2.60 \pm 0.89^{\mathrm{a}}$ \\
\hline $\mathrm{P}-\mathrm{O}$ & $\mathrm{O}$ & $57.49 \pm 25.82^{\mathrm{a}}$ & $6.62 \pm 2.83^{\mathrm{a}}$ & $15.76 \pm 8.53^{\mathrm{a}}$ & $1.22 \pm 0.37^{\mathrm{b}}$ & - & - & - \\
& $\mathrm{A}$ & $6.98 \pm 4.79^{\mathrm{a}}$ & $0.81 \pm 0.43^{\mathrm{ab}}$ & $1.66 \pm 0.70^{\mathrm{b}}$ & $0.75 \pm 0.32^{\mathrm{a}}$ & $88.40 \pm 5.32^{\mathrm{a}}$ & $9.80 \pm 5.07^{\mathrm{ab}}$ & $1.80 \pm 0.84^{\mathrm{a}}$ \\
\hline $\mathrm{O}$ & $\mathrm{A}$ & $59.10 \pm 53.73^{\mathrm{a}}$ & $8.02 \pm 7.41^{\mathrm{a}}$ & $12.17 \pm 6.91^{\mathrm{a}}$ & $1.58 \pm 0.92^{\mathrm{a}}$ & $80.40 \pm 5.86^{\mathrm{b}}$ & $17.00 \pm 6.04^{\mathrm{a}}$ & $2.60 \pm 1.52^{\mathrm{a}}$ \\
& $\mathrm{AB}$ & $10.32 \pm 6.41$ & $1.16 \pm 0.63$ & $2.75 \pm 1.11$ & $0.85 \pm 0.13$ & $79.00 \pm 11.20$ & $18.00 \pm 11.05$ & $3.00 \pm 1.00$ \\
\hline
\end{tabular}

Different small letters in the upper index of the mean values mean significant differences; $\mathrm{P}$ - pine forest, $\mathrm{O}$ - oak forest, $\mathrm{P}-\mathrm{O}$ - mixed-species stand (pine + oak); sand, silt, clay [\%]; $\mathrm{Ca}^{2+}, \mathrm{Mg}^{2+}, \mathrm{K}^{+}, \mathrm{Na}^{+}\left[\mathrm{mg} \cdot \mathrm{kg}^{-1}\right]$.

lowest rate of decomposition was observed in soil of pine stands ( 27 for organic horizon and 23 for humus mineral horizon). Texture of the investigated soils was dominated by sand (79-91\%) with admixture of silt (6-18\%) and clay (2-3\%) (Table 2).

The highest dehydrogenase activity was noted in the humus mineral horizons in soils of oak and in the organic horizon of mixed-species stand (Table 1). On the contrary, the lowest DH activity was found in organic and humus mineral horizons in soils under pine and in the humus mineral horizon under mixedspecies stands. Urease activity in the humus horizons of oak stands was significantly higher than activity in comparable horizons of pine and mixed-species stands. Most frequently, differences in the properties of soils between pine and oak stands were reported. Less frequently, differences in the properties of soils of pine and mixed-species stands and between soils of oak and mixed-species stands were observed (Table 1 and 2).

A projection of the variables on the factor-plane clearly demonstrated correlations between the physicchemical soil properties, enzyme activity and the tree species (Fig. 2). Two main factors had a significant total impact $(68.13 \%)$ on the variance of the variables. Factor 1 explained $52.64 \%$ of the variance of the examined properties, and Factor 2 explained $15.49 \%$ of the variance (Fig. 2). Soil under oak stands was connected with the highest enzyme activity and $\mathrm{pH}$ of soil. Anyhow, soil of pine stands was correlated with $\mathrm{C} / \mathrm{N}$ ratio. What is more in that soil the highest $\mathrm{C} / \mathrm{N}$ ratio was noted (Fig. 2).

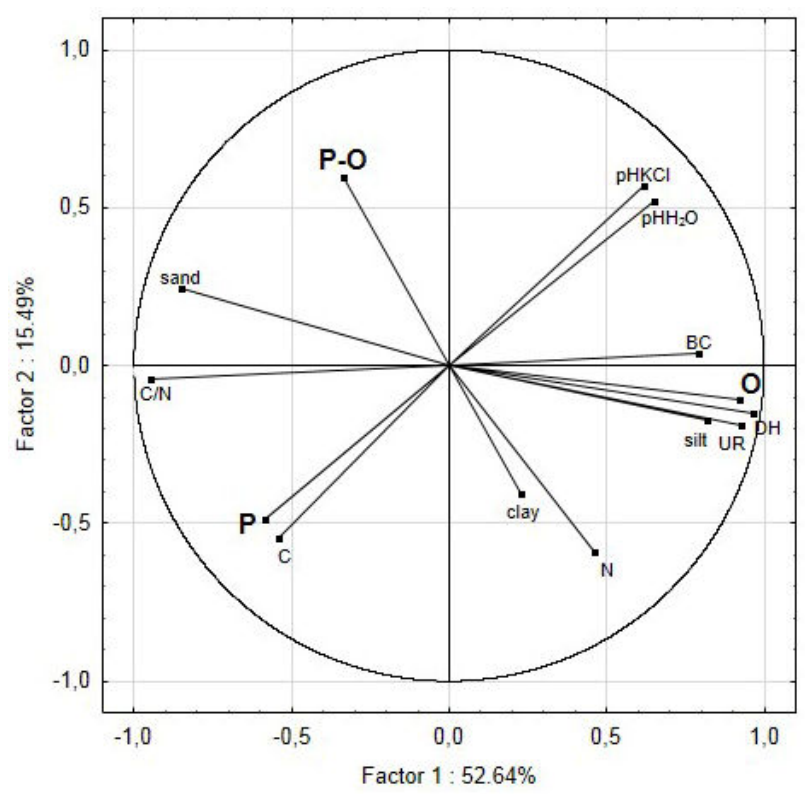

FIGURE 2. Projection of the variables on the factor-plane in soils. The forest stands were included in the analysis as three supplementary variables ( $\mathrm{O}$ - oak; $\mathrm{P}$ - pine; $\mathrm{P}-\mathrm{O}$ mixed forest $)$

\section{DISCUSSION}

Changes in the species composition of forest stands lead to modifications of soil properties. Tree species affect soil organic matter accumulation, $\mathrm{pH}$ and 
microbial activity. Our studies confirmed the positive effect of oak and mixed-species stands on $\mathrm{pH}$ in the surface soil horizons. The stands were tested according to the acidification effect on soils: pine stand $>$ mixed species stand (pine + sessile oak) $>$ sessile oak stand. Generally coniferous species have more acidifying effects on soil than deciduous species (Augusto et al. 2002, Gruba and Mulder 2015, Błońska et al. 2016). Pine contributes in the acidification of soils, and contains acid reacting buffer substances. $\mathrm{pH}$ is a major factor affecting microbial community composition and volume while $\mathrm{pH}$ affects enzyme dynamics (Wolińska et al. 2015, Błońska et al. 2016). The highest enzyme activity in our study was reported in the soil of oak and mixed-species stands where at the same time $\mathrm{pH}$ reached maximal values (4.71). The $\mathrm{pH}$ in control soils affected on enzymatic activity by influencing enzyme confirmations and the adsorption of soil colloids (Turner 2010, Šnajdr et al. 2013). In addition, the activity of the enzymes showed a strong relationship with the content of fine fractions, especially silt. In this study soil with the highest dehydrogenase and urease activities simultaneously were characterized by increase of pH and content of silt. Gianfreda et al. (2005) noted a correlation between enzymatic activity and the content of clay, sand and silt. Soil of oak stands showed a higher silt content which resulted in higher dehydrogenases and urease activities. A slight difference in the content of fine fractions changes the physical properties and conditions of microbial growth. The higher content of silt improves soil structurality. According to Drążkiewicz (1989) the greater amount of aggregates in the soil and the more complex of the structure, the more favorable conditions for the development of various groups of microorganisms. The one soil aggregate is different zone of microniche, differing in the substrate quantity, the amount of oxygen and $\mathrm{pH}$. Proper soil structure promotes the decomposition of organic matter, which is a source of food for soil microorganisms (Cui and Holden 2015). The significance of coarser particles than clay for biological activity was highlighted by von Lützow et al. (2007).

The trees can modify the environment by changing their crown and canopy structure (Pretzsch 2014). The mixing of species with differing ecological traits may enhance structural complexity above and below ground which can increase stand productivity compared with monocultures (Forester and Bauhus 2016). The stand affects quality and quantity of soil organic matter through diversified structure and thus the diverse fallout of plant remains. Our study clearly demonstrated that mixed stands are characterized by intermediate degree of decomposition of organic matter. The $\mathrm{C} / \mathrm{N}$ ratio is often used to describe the litter quality, and broadleaf species have lower $\mathrm{C} / \mathrm{N}$ ratio than pine (Handsson et al. 2011). A lower $\mathrm{C} / \mathrm{N}$ ratio was found in oak and mixed-species stands compared with pine stands. We also noted correlation between enzyme activity and $\mathrm{C} / \mathrm{N}$ ratio. Correlation of enzymes activity with the $\mathrm{C} / \mathrm{N}$ ratio confirms the importance of the quality of organic matter provided by different tree species. The ratio of the percentage of carbon to nitrogen in the soil $(\mathrm{C} / \mathrm{N})$ is an indicator of the degree to which nitrogen contained in plant remains is available to microorganisms (Błońska 2015).

The obtained results confirm usefulness of biochemical properties of soils in study the relationship between vegetation and soil. Biochemical and chemical properties can be used for show the results of forest management on soils. The knowledge of the relation between soil properties and species composition of stands will contribute to improving the management and protection of forest soils. The results confirmed that breeding of mixed-species stands provides the maintenance of proper condition of the soil. Breeding of poor monoculture on mesotrophic sites leads to a deterioration of soil quality.

\section{CONCLUSIONS}

1. Stand mixing improves soil properties, especially the quality of soil organic matter and biochemical properties. The results confirmed that breeding of mixed-species stands provides the maintenance of proper condition of the soil.

2. Mixed stands compared to monocultures stands causes a higher microbial activity expressed as dehydrogenase and urease activities.

3. The positive effect of oak and mixed-species stands on acidification of surface soil horizons was evidenced.

4. The knowledge of the relation between soil properties and species composition of forest stands will contribute to improving the management and protection of forest soils.

\section{ACKNOWLEDGMENTS}

The project was financed by the Polish Committee of Scientific Research (NN309297534) 


\section{REFERENCES}

Alef K., Nannipieri P., 1995. Enzyme activities. [In:] Methods in applied Soil Microbiology and Biochemistry (Alef K., Nannipieri P., Editors). Academic Press, London, New York, San Francisco, 311-373.

Augusto L., Ranger J., Binkley D., Rothe A., 2002. Impact of several common tree species of European temperate forests on soil fertility. Annals of Forest Science 59: 233-253.

Błońska E., 2015. Effect of stand species composition on the enzyme activity and organic matter stabilization in forest soil. Scientific papers of University of Agriculture in Kraków No. 527. Dissertation, Paper No 404: 1-05.

Błońska E., Lasota J., Gruba P., 2016. Effect of temperate forest tree species on soil dehydrogenase and urease activities in relation to other properties of soil derived from loess and glaciofluvial sand. Ecological Research 31(5): 655-664.

Cui J., Holden N.M., 2015. The relationship between soil microbial activity and microbial biomass, soil structure and grassland management. Soil and Tillage Research 146: 32-38.

Drążkiewicz M., 1989. Relacje pomiędzy fazą stała gleby a mikroorganizmami. Postępy Mikrobiologii 28(2-4): 161-171.

Forrester D.I., Bauhus J., 2016. A review of processes behind diversity - productivity relationships in forests. Current Forestry Reports 2: 45-61.

Gałka B., Kabała C., Łabaz B., Bogacz A., 2014. Influence of stands with diversed share of Norway spruce in species structure on soils of various forest habitats in the Stołowe Mountains. Sylwan 158: 684-694.

Gianfreda L., Rao A.M., Piotrowska A., Palumbo G., Colombo C., 2005. Soil enzyme activities as affected by anthropogenic alterations: intensive agricultural practices and organic pollution. Science of the Total Environment 341(1-3): 265-279.

Gruba P., Mulder J., 2015. Tree species affect cation exchange capacity (CEC) and cation binding properties of organic matter in acid forest soils. Science of the Total Environment 511: $655-662$.

Handsson K., Olsson B.A., Olsson M., Johansson U., Kleja D.B., 2011. Differences in soil properties in adiacent stands of Scots pine, Norway spruce and Siver birch in SW Sweden. Forest Ecology and Management 262: 522-530.

Jandl R.M., Lindner M., Vesterdal L., Bauwens B., Baritz R., Hagedorn F., Johnson D.W., Minkkinen K., Byrne K.A., 2007. How strongly can forest management influence soil carbon sequestration? Geoderma 137: 253-268.

Lasota J., Błońska E., 2013. Siedliskoznawstwo leśne na nizinach i wyżynach Polski. Wydawnictwo Uniwersytetu Rolniczego w Krakowie, 236 ss.

Łabaz B., Gałka B., Bogacz A., Waroszewski J., Kabała C., 2014. Factors influencing humus forms and forest litter properties in the mid-mountains under temperate climate of southwestern Poland. Geoderma 230/231: 265-273.
Paluch J., Gruba P., 2012. Effect of local species composition on topsoil properties in mixed stands with silver fir (Abies alba Mill.). Forestry 85: 413-426.

Pretzsch H., 2014. Canopy space filling and tree crown morphology in Mied-species stands compared with monocultures. Forest Ecology and Management 327: 251-264.

Pretzsch H., del Río M., Ammer Ch., Avdagic A., Barbeito I., Bielak K., et al. 2015. Growth and yield of mixed versus pure stands of Scots pine (Pinus sylvestris L.) and European beech (Fagus sylvatica L.) analysed along a productivity gradient through Europe. European Journal of Forest Research 134(5): 927-947.

Pretzsch H., del Rio M., Schütze G., Ammer Ch., Annighöfer P., et al. 2016. Mixing of Scots pine (Pinus sylvestris L.) and European beech (Fagus sylvatica L.) enhances structural heterogeneity, and the effect increases with water availability. Forest Ecology and Management 373: 149-166.

Richards A.E., Forrester D.I., Bauhus J., Scherer-Lorenzen M., 2010. The influence of mixed tree plantations on the nutrition of individual species: A review. Tree Physiology 30: 11921208.

Río M., Sterba H., 2009. Comparing volume growth in pure and mixed stands of Pinus sylvestris and Quercus pyrenaica. Annals of Forest Science 66(5): 1-11.

Río M., Condés S., Pretzsch H., 2014. Temporal variation of competition and facilitation in mixed species forests in Central Europe. Plant Biology 16: 166-176.

Šnajdr J., Dobiášová P., Urbanová M., Petránková M., Cajthaml T., Frouz J., Baldrian P., 2013. Dominant trees affect microbial community composition and activity in postmining afforested soils. Soil Biology and Biochemistry 56: $105-115$.

StatSoft, Inc. 2010. STATISTICA (version 9.0). Computer software.

Tabatabai M.A., Bremner J.M., 1972. Assay of urease activity in soils. Soil Biology and biochemistry 4: 479-487.

Turner B.L., 2010. Variation in pH optima of hydrolytic enzyme activities in tropical rain forest soils. Applied and Environmental Microbiology 76: 6485-6493.

Wolińska A., Stępniewska Z., Pytlak A., 2015. The effect of environmental factors on total soil DNA content and dehydrogenase activity. Archives of Biological Sciences 67 (2): $493-$ 501.

WRB (World Reference Base For Soil Resource), 2006. FAO, ISRIC and ISSS.

von Lützow M., Kögel-Knabner I., Ekschmitt K., Flessa H., Guggenberger G., Matzner E., Marschner B., 2007. SOM fractionation methods: Relevance to functional pools and to stabilization mechanisms. Soil Biology and Biochemistry 39: 2183-2207.

Received: October 18, 2016

Accepted: January 16, 2017

Associated editor: J. Wyszkowska 


\section{Wpływ zmieszania drzewostanu na aktywność enzymatyczną i pozostałe wlaściwości gleb}

Streszczenie: W badaniach aktywność enzymatyczna została wykorzystana do oceny różnic powstałych w glebach w wyniku wpływu różnych gatunków drzew. Celem badań była ocean wpływu sosny zwyczajnej (Pinus sylvestris), dębu szypułkowego (Quercus robur) i drzewostanów mieszanych na aktywność enzymatyczną i chemiczne właściwości gleb. Powierzchnie badawcze zostały zlokalizowane w centralnej Polsce, w Nadleśnictwie Przedbórz (51.09.59.50 $\left.\mathrm{N}, 20.00 .24 .25^{\circ} \mathrm{E}\right)$. Teren badań był zdominowany przez gleby rdzawe brunatne. 15 powierzchni badawczych zostało założonych ( 5 powierzchni pod sosna, 5 powierzchni pod dębem i 5 powierzchni pod drzewostanem mieszanym). Do analiz zostały pobrane próbki gleb z poziomów O, A i AB. W próbkach gleb oznaczono: pH, uziarnienie, zawartość węgla i azotu, zawartość kationów zasadowych, aktywność dehydrogenaz i ureazy. Zmiany w składzie gatunkowym drzewostanu doprowadziły do modyfikacji właściwości gleb. Gatunki drzew oddziałują na akumulację glebowej materii organicznej, pH i mikrobiologiczną aktywność gleb. Najwyższą aktywność enzymatyczną odnotowano w glebach drzewostanów dębowych i mieszanych. pH było niższe w glebach drzewostanów sosnowych w porównaniu do gleb drzewostanów dębowych i mieszanych. $\mathrm{pH}$ jest prawdopodobnie głównym czynnikiem wpływającym na aktywność mikrobiologiczną i dynamikę enzymów. Dodatkowo zanotowaliśmy korelacje pomiędzy aktywnością enzymów i stosunkiem $\mathrm{C} / \mathrm{N}$, który jest wykorzystywany w ocenie jakości ścioły. Niski stosunek $\mathrm{C} / \mathrm{N}$ charakteryzował gleby drzewostanów dębowych i mieszanych w porównaniu do gleb sośnin.

Słowa kluczowe: glebowa materia organiczna, aktywność dehydrogenaz i ureazy, gleby leśne, dąb, sosna 